\title{
MEET THE GUEST EDITOR
}

\author{
Sibel A. Ozkan \\ Department of Analytical Chemistry \\ Faculty of Pharmacy \\ Ankara University \\ 06100 Tandogan \\ Ankara \\ Turkey \\ E-mails: ozkan@pharmacy.ankara.edu.tr ; sibelaysil@gmail.com
}

Sibel A. Ozkan studied at Ankara University, from where she received her Pharmacy degree in 1985 . She obtained her Master's (1988) and PhD (1994) degrees in the same university, Analytical Chemistry Department. She has become full professor 2003. She has been involved in several analytical chemistry projects related to electroanalytical chemistry and separation techniques on drug active compounds and DNA-Drug interactions. She has organized and participated in organizing committees of a number of international meetings related to Pharmaceutical Sciences (Series of ISOPS-Ankara-Turkey). Her research interest focuses on the electrochemical investigations of pharmaceutically active compounds and their analysis using electroanalytical, chromatographic and spectrophotometric methods, and their validations. Her research area currently moves to the development of DNA biosensors and their interactions with drugs. She is currently a faculty member at the Analytical Chemistry Department at Faculty of Pharmacy, Ankara University.

Prof. Ozkan is a member of Editorial Board of Chromatographia, Talanta, The Open Analytical Chemistry Journal, The Global Journal of Analytical Chemistry, Journal of Hacettepe University- Faculty of Pharmacy, and Journal of Pharmaceutical Sciences (FABAD). She was Vice Editor of the Special Issue of Chromatographia Vol. 66, 2007, "Application of Separation Techniques in Turkey" with Dr. Henk Lingeman (Chromatographia Editor). She was also Guest Editor of the Special Issue of Combinatorial Chemistry \& High Throughput Screening 2010 (Volume 13 issues 6; 7; 8): "Applications of Analytical Methods: Prospects for High Throughput Screening of Pharmaceutically Active Compounds". She is active as a referee with leading analytical chemistry journals as Talanta, Electrochimica Acta, Analytica Chimica Acta, Chromatographia, Analytical Letters, Sensors and Actuators B, Biosensors \& Bioelectronics, Journal of Separation Science etc. She received Ankara University Scientific Promotion Award in 2003 and Turkish Pharmaceutical Association, Academy of Pharmacy Science Award in 2008. Prof. Ozkan is an author of 120 original and review papers. Some selected publications are cited below.

\section{SELECTED PUBLICATIONS}

[1] Yang, Z.; Kauffmann, J.-M.; Acedo Valenzuela, M.I.; Ozkan, S.A. Electroanalytical behavior of a nanoarray self-assembled thiocholesterol gold electrode. Microchim. Acta, 1999, 131, 85-90.

[2] Ozkan, S.A.; Uslu, B.; Zuman, P. Electrochemical oxidation of sildenafil citrate (viagra) on carbon electrodes. Anal. Chim. Acta, 2004, 501, $227-233$.

[3] Uslu, B.; Ozkan, S.A. Anodic voltammetry of abacavir and its determination in pharmaceuticals and biological fluids. Electrochimica Acta, 2004, 49, $4321-4329$.

[4] Golcu, A.; Dogan, B.; Ozkan, S.A. Anodic voltammetric behavior and determination of cefixime in pharmaceutical dosage forms and biological fluids. Talanta, 2005, 67, 703-712.

[5] Dogan, B.; Ozkan, S.A. Electrochemical behavior of carvedilol and its adsorptive stripping determination in dosage forms and biological fluids. Electroanalysis, 2005, 17, 2074-2083.

[6] Ostatna, V.; Uslu, B.; Dogan, B.; Ozkan, S.A.; Palecek, E. Native and denatured bovine serum albumin. DC polarography, stripping voltammetry and constant current chronopotentiometry. J. Electroanal. Chem., 2006, 593, 172-178.

[7] Dogan, B.; Tuncel, S.; Uslu, B.; Ozkan, S.A. Selective electrochemical behavior of highly conductive boron-doped diamond electrodes for fluvastatin sodium oxidation. Diamond Relat. Mater., 2007, 16, 1695-1704.

[8] Dogan-Topal, B.; Uslu, B.; Ozkan, S.A.; Zuman, P. Electrochemical determination of HIV drug Abacavir based on its reduction. Anal. Chem., 2008, $80,209-216$.

[9] Dogan-Topal, B.; Uslu, B.; Ozkan, S.A. Voltammetric studies on the HIV-1 inhibitory drug Efavirenz: the interaction between dsDNA and drug using electrochemical DNA biosensor and adsorptive stripping voltammetric determination on disposable pencil graphite electrode. Biosens. Bioelectron., 2009, 24, 2358-2364.

[10] Dogan-Topal, B.; Bozal B.; Demircigil, B. T.; Uslu, B.; Ozkan, S.A. Electroanalytical studies and simultaneous determination of amlodipine besylate and atorvastatine calcium in binary mixtures using first derivative of the ratio-voltammetric methods. Electroanalysis, 2009, 21, $2427-2439$. 